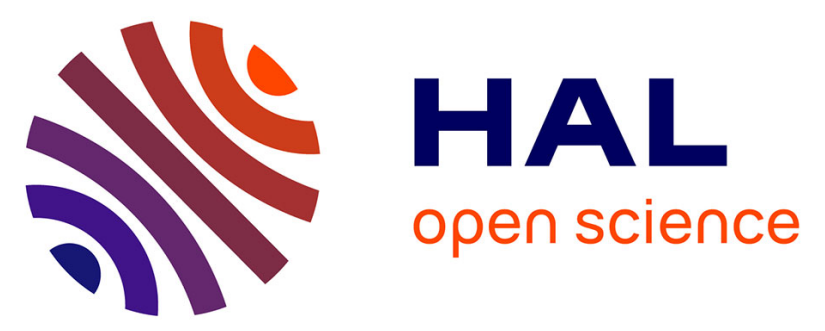

\title{
Terahertz Non-Destructive Thickness Characterization of Optically Thin Scale Layers on Steel
}

\author{
Min Zhai, A. Locquet, Cyrielle Roquelet, D.S. Citrin
}

\section{To cite this version:}

Min Zhai, A. Locquet, Cyrielle Roquelet, D.S. Citrin. Terahertz Non-Destructive Thickness Characterization of Optically Thin Scale Layers on Steel. 2019 44th International Conference on Infrared, Millimeter, and Terahertz Waves (IRMMW-THz), Sep 2019, Paris, France. pp.1-1, 10.1109/IRMMW-

THz.2019.8874181 . hal-03084718

\section{HAL Id: hal-03084718 \\ https://hal.science/hal-03084718}

Submitted on 21 Dec 2020

HAL is a multi-disciplinary open access archive for the deposit and dissemination of scientific research documents, whether they are published or not. The documents may come from teaching and research institutions in France or abroad, or from public or private research centers.
L'archive ouverte pluridisciplinaire HAL, est destinée au dépôt et à la diffusion de documents scientifiques de niveau recherche, publiés ou non, émanant des établissements d'enseignement et de recherche français ou étrangers, des laboratoires publics ou privés. 


\title{
Terahertz Non-Destructive Thickness Characterization of Optically Thin Wüstite Layers on Steel
}

\author{
Min Zhai ${ }^{1,2}$, Alexandre Locquet 1,2 , Roquelet Cyrielle ${ }^{3}$, D.S. Citrin ${ }^{1,2}$ \\ 1.Georgia Tech-CNRS UMI2958, Georgia Tech Lorraine, 2 Rue Marconi, 57070 Metz France \\ 2. School of Electrical and Computer Engineering, Georgia Institute of Technology, Atlanta, Georgia 30332-0250 USA \\ 3. ArcelorMittal Maizières Research SA, Voie Romaine, 57280 Maizières-lès-Metz, France
}

\begin{abstract}
Terahertz imaging is a relatively new technique for nondestructive evaluation. Compared with the destructive micro-cut technique that provides information along the line of cut only, THz imaging nondestructively provides a global mapping of a sample. Hence, this technique has been applied to characterize coated materials and composite laminates. In this work, we characterize optically thin wüstite layers on steel leveraging signal-processing techniques.
\end{abstract}

\section{INTRODUCTION}

Monitoring coating thickness (paints, polymers, and oxides) on steel is a way to characterize the sample quality. A common approach is cross-section imaging, which is destructive as it requires the sample to be cut.

Terahertz (THz) imaging has attracted considerable interest as a noninvasive, noncontact, nonionizing and nondestructive evaluation method to characterize various nonmetallic materials with single- or multi-layered structures.

Specifically, the work focuses on thickness characterization of wüstite layers on steel based on a two-step process: (1) measuring the sample with pulsed $\mathrm{THz}$ reflectometry and (2) advanced signal processing to extract detailed features about the sample that are not immediately evident in the signals collected in the first step. Three wüstite films of thickness 28.5, 13.4, and $5.1 \mu \mathrm{m}$ were provided by ArcelorMittal.

Three innovative approaches, frequency-wavelet domain deconvolution (FWDD) ${ }^{1}$, sparsity-based deconvolution $(\mathrm{SD})^{2}$ and autoregressive spectral extrapolation (AR) ${ }^{3}$ are applied to demonstrate the structural properties of samples with different thicknesses.

\section{RESULTS}

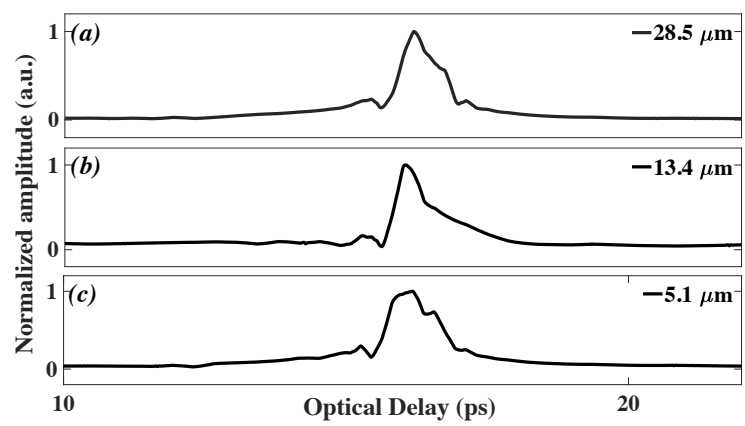

Fig. 1 FWDD deconvolved signal for films of different thickness.

Figure 1 shows that, after applying the FWDD method, only one pulse can be identified in the signal reflected by the samples, implying that the optical thickness of the oxide layer on steel substrate is beyond the capability of the FWDD algorithm.

When applying the SD approach, however, an additional small echo, originating in the wüstite/steel interface, can be seen clearly as shown in Fig. 2. The layer thickness can be estimated from the time delay between the two peaks, to be $28.4 \mu \mathrm{m}, 12.8 \mu \mathrm{m}$ and $9.6 \mu \mathrm{m}$, respectively. It is thus clear that the thickness of the thinnest layer cannot be accurately characterized with SD.

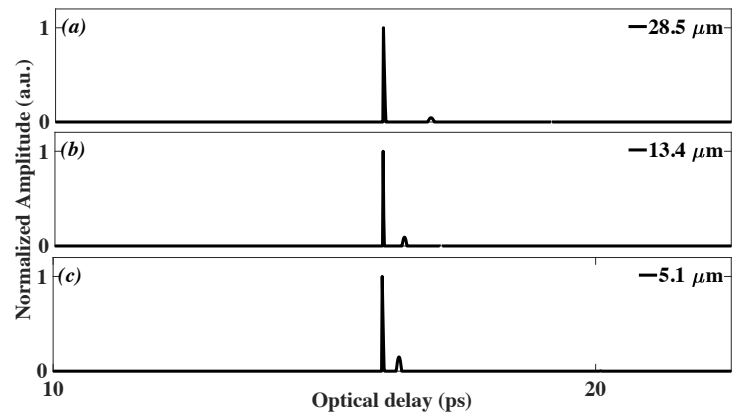

Fig. 2 SD deconvolved signals for films of different thickness. Two peaks corresponding to the top and bottom interfaces of the wüstite layers are clearly observed. The second peak corresponds to the wüstite/steel interface.

AR is a model that exploits the data in high-SNR regions to estimate the components in low-SNR regions. The results of AR are illustrated in Fig. 3. The thicknesses of all samples could be successfully measured.

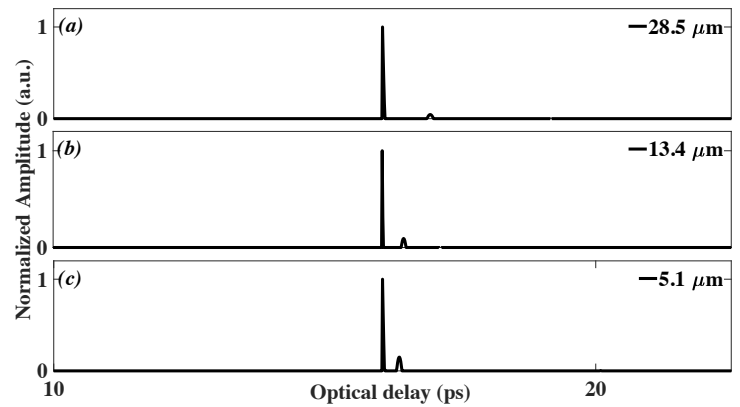

Fig. 3 AR deconvolved signals for the three different films. Two interfaces are observed in all cases.

\section{REFERENCES}

[1] J. Dong, A. Locquet, and D.S. Citrin, "Terahertz Quantitative Nondestructive Evaluation of failure modes in Polymer-Coating Steel," IEEE J. Quantum Electron, vol. 23, no. 4, 2017.

[2] J. Dong, A. Locquet, and D.S. Citrin, "Terahertz super-resolution stratigraphic characterization of multilayered structures using sparse deconvolution, " IEEE Trans. Terahertz Sci. Technol., 7, 260-267, 2017.

[3] J. Dong, A. Locquet, and D.S. Citrin, "Depth resolution enhancement of terahertz deconvolution by autoregressive spectral extrapolation," Opt. Lett, vol. 42 , no. 9, 2017. 